\title{
What's in a name: are cultured red blood cells 'natural '?
}

\section{Emma King and Catherine Lyall}

\section{Abstract}

The case of cultured red blood cells currently being grown in a laboratory for future use in human transfusion raises questions about the ontological status of such products of modern biotechnology. This paper presents results from a six-year ethnographic study involving interviews, focus groups and other forms of engagement with the scientific research team and other stakeholders, including public groups, which sought to understand respondents' reactions to cultured red blood cells. These cells, derived from stem cell technology, have the potential to address the global shortage of donated blood. How these blood cells are situated within the spectrum of 'natural' to 'synthetic' will shape expectations and acceptance of this product, both within the scientific community and by wider publics: these blood cells are both novel and yet, at the same time, very familiar. Drawing on discussions related to classification and 'anchoring', we examine the contrasting discourses offered by our respondents on whether these blood cells are 'natural' or not and consider the impact that naming might have on both their future regulation and the eventual uptake of cultured red blood cells by society. [183 words] 


\section{Introduction}

Cultured red blood cells (RBCs), grown in a laboratory for use in transfusion, are a potential new technology that could reduce or eliminate future need for blood donors by supplying an abundant stock of infection-free red blood cells (Trakarnsanga et al. 2017). Chemical-based blood substitutes have had only limited clinical success, and cultured red blood cells represent a method of achieving adequate quantities for transfusion by culturing stocks of human red blood cells under laboratory conditions. A potentially limitless supply of red blood cells would safeguard the current transfusion services against decreasing donor numbers and increased infection risk, and provide a potential source of transfusion for countries that do not currently have access to safe blood supplies.

How these blood cells are situated within the spectrum of 'natural' or 'synthetic' will shape our expectations and acceptance of this product, both within the scientific community and by wider publics. Cultured RBCs are one of those 'ontological novelties created by biotechnology' (Jasanoff 2005) and the naming process will, in part, help us to decide which side of the boundary they lie: whether they are 'familiar and manageable' or 'unknown and perhaps insupportably risky' (ibid.). As Hauskeller (2005) suggests, '[N]aming shapes both the cultural and the scientific perception of the object' while 'the performative power of language establishes objects as possible discursive and regulatory targets' (ibid.). Blood and blood donation are emotive topics, imbued with major cultural significance, for example linked to kinship and family ties (e.g. Carsten 2011) and notions of altruism (Titmuss 1970). In this case we are dealing with only one component of 'blood': individual, red blood cells 
rather than the whole blood that is extracted during a donation session. These cultured red blood cells would be biologically indistinguishable from human donor red blood cells. How this product is defined could also impact on regulation of the cultured blood product, depending on whether it is viewed as comparable either with existing blood transfusions or with pharmaceutical products.

In this paper we discuss how these cells can be seen as liminal products, crossing the boundaries between different expectations of what red blood cells are. 'Un-naturalness' has been a recurrent theme in social research on the public acceptability of new products arising from biotechnology (for example, Hansen 2006; Dragojlovic and Einsiedel 2013; Nuffield Council on Bioethics 2015). We frame this paper within this context of what is 'natural' and draw on the concept of 'anchoring' (e.g. Marcu et al. 2015) to describe how research participants understood the ontological nature of this novel product.

We use this concept to demonstrate how, during our study, we identified the blood project research team as 'anchoring' the proposed cultured blood product very firmly to the ideal of 'normal' blood. Other research informants, drawn from different public groups, also exhibited anchoring to normal blood but, we shall argue, did so for different reasons.

In the next section we provide background to the cultured blood project, including work to date on alternative blood products, which demonstrates that this current study on stem cell derived tissue represents a unique piece of research within the sociology of health and illness. We next give a brief overview of the literature that has shaped our thinking on the ways in which the concept of 'natural' is understood in the context of novel, biological products. 
We then present empirical data to compare how the blood project research team described the cultured red blood cells (RBCs) in contrast to how our research participants talked about them. In examining these different discourses we discuss the natural/unnatural distinction that appears to be being drawn and the impact that naming might have on both the future regulation of this new product and the eventual wider uptake of cultured RBCs.

\section{Background}

The BloodPharma project, which subsequently changed its name to Novosangi, is a research collaboration funded by the Wellcome Trust and the Scottish Funding Council to develop an alternative method of producing RBCs for use in human transfusion. This research uses stem cell technology, with the eventual aim of producing an unlimited supply of O negative (the near universal donor) RBCs. Early stages of the research used human embryonic stem cells (hESCs) to develop proof of concept and the project subsequently moved towards the use of induced pluripotent stem cells (iPSCs) from adult donors (Mountford 2008; Mountford and Turner 2011).

The data for this paper come from an ethnographic study conducted by King (2013), which followed the work of the blood project research team, plus the work of Lyall and King (2016) as embedded social researchers within the same team, which subsequently sought the views of wider publics towards cultured red blood cells. Our methods are discussed in more detail below.

Blood use and alternative products 
Transfusions of red blood cells are crucial to modern medical practice to overcome blood loss through injury, during surgery, or for those conditions that result in severe anaemia (McRoberts et al. 2007). Currently, these transfusions are reliant on human donors, who are altruistic in the UK but may be paid in other countries. The UK is fortunate in possessing an established donation system and a reasonably reliable and steady source of donated blood, although fluctuations in donor numbers do occur. There are many countries around the world that do not have a reliable source of safe blood and it is these who may benefit long term from cultured blood products (Bessos et al. 2008).

Even in established blood donation systems there is the potential for transfusion-transmitted infections (TTIS), many of which have long latency periods and may not be detected until months or years after the infected blood was transfused. Patient groups who receive regular blood products or full transfusions are especially at risk and compensation running into many millions of pounds has already been paid to those who have contracted TTIs (Starr 1999).

The current transfusion services face challenges that highlight the need for a future alternative to red blood cells from donors. Donor numbers are declining at the same time as global medical need is rising, and the possibility of TTIs has resulted in increasing restrictions on donors and more extensive disease testing.

Chemical-based blood substitutes such as perfluorocarbons (PFCs) (Cohn and Cushing 2009) have previously been developed but none has passed the strict tests required to become a clinical product in the UK or US. Methods of bloodless surgery, cell salvage, the use of drugs such as tranexamic acid that reduce blood loss and pre-operative autologous donation are also becoming more common and have reduced usage in a number of applications such as 
major surgery (Li et al. 2017; Weltert et al. 2013). Previous attempts have been made to culture blood from other means (e.g. bone marrow and cord blood), however the number of units that can be generated from a single donor using these sources is limited.

\section{Previous work on blood/blood substitutes}

Development of a novel method of obtaining red blood cells for transfusion cannot become a substitute for conventional blood donation unless the factors determining uptake are understood. Trust is seen to have a direct impact on the acceptance of technologies, which in turn impacts on how many people are willing to use such technologies and on their potential market value (Siegrist 2000; Bates et al. 2010).

Yet, to date, few research projects have specifically examined public attitudes to the use of blood replacement technologies. Previous social research looking at attitudes to blood, itself, has addressed the 'gift relationship' (Titmuss 1970), and the 'biovalue' (Waldby 2002) of blood and is generally situated within the wider field of tissue and organ donation and transfusion.

The EuroBloodSubstitutes projectii represents one of the few studies on public attitudes to blood substitutes, and this work did not include research on stem cell derived technology. The study carried out by Fleming et al. (2007) into the risks and ethics associated with different blood types and substitutes found that those studied had a preference for donor blood, being regarded as the most effective, most ethically acceptable and least 'risky'. Despite the infection scandals that have been associated with human donor blood, the Fleming study shows that this is still the preferred option by those who were interviewed. 
Ferguson et al.'s (2008) work showed that perceived risk was inversely proportional to acceptability, however the perceived risk of blood substitutes varied considerably between the two countries studied in the paper (the UK and Holland), showing the importance of societal factors in acceptability. Other research on blood and blood substitutes has identified a greater acceptability of blood substitutes amongst medical professionals, when compared with journalists or blood donors (Lowe et al. 2001).

Ferguson et al. (2008) discovered that the public viewed blood substitutes as a 'substandard replacement' for actual blood, an unnatural and synthetic alternative, although the writers argue that this view may be changed by a more effective 'marketing' of alternative blood products than had been seen with previous synthetic products such as Haemoglobin Based Oxygen Carriers (HBOCs). Of most relevance to our study is Ferguson et al.'s reference to 'narrative priming', in which they refer to the naming of 'blood substitutes' as potentially being a reason for lower acceptability. This is because 'substitute' is most often used to refer to a substandard alternative, or one that is only used when the original ingredient is not available. Hence Ferguson's call to look more closely at the message framing of blood substitutes and how information is presented to the public.

Not considered by Fleming et al. (2007) is the attachment that the public have to blood donation due to the principle of altruism and gift giving, which remains a driving force behind the blood transfusion services in the UK, over forty years after the publication of Titmuss' work.

The lack of literature specifically on attitudes towards alternative sources of blood, and the fact that the EuroBloodSubsitutes project did not include stem cell derived technology, means 
there is, to date, little basis on which to judge how the public may react to the use of cultured red blood cells from stem cells. Our ethnographic study of the BloodPharma project seeks to address this gap.

\section{Classifying and situating new technologies}

When people seek to make sense of the new and unfamiliar they do so through a social process. Social representations theory (Voelklein and Howarth, 2005) has been used to explain how social and cultural conditions shape how an entity (in particular, a novel entity) is perceived (Moscovici, 1961). This social constructionist approach relies on a process of 'anchoring' where 'what is novel and unfamiliar is rendered familiar by being located (or anchored) in existing frames of knowledge' (Marcu et al., 2015). Kronberger (2015) defines 'anchoring' as 'the process of classifying, categorizing and naming the unknown' and goes on to describe how:

'By giving a name to the unfamiliar, it is linked to a multitude of references, out of which it takes a shape that is familiar and understandable... anchoring the unknown is also linked to social values, and thereby becomes integrated into an existing moral order. Classifying the unknown as something of a specific kind implies evaluation according to the criteria of good and bad, normal and abnormal' (Kronberger 2015).

This process of anchoring thus draws on analogies, metaphors, and contrasts (Marcu et al., 2015). Those working in the sociology of scientific knowledge tradition would also argue that how we classify things is not pre-determined by 'reality' (Marks 2010, p.33) and, instead, we must understand classifications as socially sustained 'institutions' (Barnes 1983). Thus, 'when 
we encounter a new object, we extend our classification by analogy and not by identity' (Barnes et al. 1996: 56, cited in Marks, ibid.). Language and naming are used both to explain objects that are unfamiliar, and also to influence or reassure others (Wright Mills 1940).

Hauskeller (2005), citing Vogelstein et al. (2002), demonstrates how scientists manipulate terms in order to 'achieve goals of scientific freedom' through naming:

\footnotetext{
'the way in which objects or goals are described or named is never simply an objective reference. Any language use - however, strategic or unconsciously motivated - must invoke former uses of the same or similar words or phrases and hence evokes a particular set of images and associations while preventing others. The language of science guides the awareness and perception of these who employ it.' (Hauskeller, 2005)
}

The concept of 'nature' can also be a powerful rhetorical tool (Marks 2010, p.42) with concepts of what is 'natural' often mobilised to give authority to particular classifications (Marks 2010, p.44): 'natural' is equated with 'normal' and other positive attributes (Parry and Dupre 2010). The opposite of natural can be one of two things: the non-natural (i.e. artificial or synthetic) and the unnatural in the sense of 'abnormal' (Fox Keller 2008). In analyses of public discourses on genetics and biotechnology, vocabulary such as 'natural' and 'naturally' have been shown to be used ideologically (Hansen 2006) in ways that convey a sense of 'ontological permanence' (Harvey 1996, quoted in Hansen 2006) or 'common consensus' that therefore does not require further debate, in contrast with something that is 'non-natural'. This latter implies the requirement for further discussion or explanation as it 
may be regarded as something that is 'potentially wrong, immoral, unethical, dangerous or simply 'unknown' ' (Hansen 2006).

A 'natural' entity can also be rendered abnormal or unclean simply by being 'out of place' (Douglas 1966). By being neither a synthetic chemical derivative nor a human donation, cultured blood does not fit into either category with which we are familiar, and therefore risks being rendered 'abnormal' according to Fox Keller's (ibid.) definition of 'unnatural'. It is also worth recalling that 'natural' is not always associated with acceptance: 'natural' (in vivo) blood has historically been considered 'unclean', with example of societies who excluded menstruating women (Douglas ibid.), by the marking of blood transfusions to ensure that white recipients were not receiving blood from black donors (Starr 1999, pg.109,169), and by the later HIV and Hepatitis contamination of donated blood and plasma. Despite this, studies have shown that most people still show an attachment to donor blood (Ferguson 2007, Fleming 2008, Lowe 2001).

What is described as 'natural' can reflect 'the goals and interests of those doing the classifying' (Marks 2010), as we saw above in the way that scientists manipulate terms in order to achieve goals of scientific freedom (Hauskeller, 2005).

In applying what we have read in the literature to the specific context of the BloodPharma project, we consider that there are two ways in which the label 'natural' can be discussed here. The first is the distinction between 'natural' donated (in vivo) blood and 'unnatural' cultured blood. The second is the distinction between 'natural' blood and 'artificial' chemical-based blood substitutes. Cultured and in vivo RBCs can be seen to represent 
different versions of the same biological entity iii in contrast to chemical blood substitutes, which are markedly different from either cultured or in vivo blood.

As authors we have reflected on whether cultured blood could be considered simply as a natural product made by an unnatural process and have set out to explore the 'naturalness' of cultured red blood cells in the minds of different groups of people. Swierstra et al. (2009) ask whether a longing for 'naturalness' is simply a response to the growing realisation that nature is not the only option, that advancing technology gives us the option to decide whether nature is the best option, or whether we wish to create something better. By examining whether cultured red blood cells are positioned rhetorically as 'natural' or otherwise, we explore why different groups of informants take different positions and the implications that such positions might have on the acceptance of this novel product.

\section{Methods}

We are qualitative researchers who have spent up to six years conducting ethnographic work - in various forms as we discuss below - with the blood project research team ('the BloodPharma team') who are developing cultured red blood cells. In addition, we have carried out focus groups and interviews with lay groups and with individuals involved in areas such as ethics, healthcare, and journalism. We have therefore used a variety of qualitative research methods including observation and participation in meetings, interviews with key members of the blood project research team, focus groups with publics and patient groups, and interviews with 'experts' such as ethicists. As we have discussed elsewhere in relation to this project (Lyall and King, 2016), the inherent value of a qualitative method lies in its ability to uncover new information, explore ambivalence and investigate the reasons for views, in contrast to a quantitative approach to simply 'measuring' public opinion on a topic about 
which participants may have little prior knowledge. King (2013) used expert interviews ( $N=9$ ) with members of the BloodPharma team, and observation of the laboratory and team meetings, to explore the early laboratory development of the cultured red blood cell project. Through participant observation at science festivals King also examined the way in which the BloodPharma project was presented to a wider non-scientific audience. Interviews were audio recorded, transcribed and analysed using a grounded theory approach (Strauss and Corbin, 1994).

Following on from this earlier study, King and Lyall were then invited to lead a workstream as part of a multidisciplinary, collaborative study with the BloodPharma consortium, funded by the Scottish Funding Council. Results from this study were reported in a confidential report to the BloodPharma team (King and Lyall, 2015) and a more detailed account of the method is discussed in Lyall and King (2016).

Our workstream sought to elicit the views of a wide variety of publics towards the potential use of cultured red blood cells for transfusion through a qualitative study drawing on 15 individual interviews and 12 focus groups. We used purposive rather than probabilistic sampling so, although we attempted to gather data from a wide variety of demographic groups, these results cannot be extrapolated to cover the whole population of the UK. The study brought together groups of people who were not targeted for any specific expertise in science, and who represented a range of ages, level of educational attainment, geographical location, etc. These informants were recruited through a sports club, craft groups, etc., and were an attempt to represent, as far as possible, the 'general public'.

Other key informant groups included: 
- patients who were regular users of donated blood undergoing multiple transfusions for the treatment of conditions such as thalassaemia and myelodysplasia (MDS)

- representatives of religious and moral groups who could contribute to the discussion of issues regarding cultured red blood cells from a religious or ethical standpoint

- clinical groups including nurses and doctors who have the potential to use this blood in the course of their clinical work

- members of the BloodPharma research collaboration which included stem cell scientists, physicists, bioprocessing engineers, chemists and staff from the Scottish National Blood Transfusion Service (SNBTS)

In general, we used interviews for participants whom we targeted because of their particular knowledge base (e.g. representatives of religious organisations, academics and doctors). Interviews were also conducted with patient representatives who were too geographically spread, or not in good enough health, to attend a focus group. The other informants described above were invited to contribute via focus groups (see Lyall and King, 2016 for further details of recruitment, etc.) The research underwent ethical review within the University of Edinburgh; NHS ethical review was not required as our sample did not include patients recruited through NHS boards.

Interviews and focus groups were recorded and transcribed in full. Typical of the qualitative method, our relationship between data and theory was an inductive one where data were used to derive theory rather than to test hypotheses (Thorne, 2000). Data analysis for this part of the project most closely resembled a grounded theory approach (Strauss and Corbin, 1994) with data collection taking place iteratively such that earlier findings contributed to questions asked during subsequent data collection. However, given King's long engagement 
with the topic and the research remit established by the overall collaborative project (of which we were only one workstream), a series of key themes was also identified at the outset of the project through the research questions and earlier scoping interviews. These key themes acted as 'sensitising concepts' and became thematic codes that also guided the data coding, augmenting the more grounded theory approach. Our approach to data analysis was, in reality, a mixed one, probably reflecting both the positivist and pragmatist epistemological underpinnings of grounded theory (Charmaz 2014, pp.230-232).

Our six-year engagement as embedded social scientists within an interdisciplinary but predominantly biomedical research collaboration might most accurately be described as ethnographically inspired (e.g. Marcus, 1995). If we were indeed ethnographers then our respective roles differed and indeed changed during our involvement with the BloodPharma project. At times we were, to use Bryman's terms (2012, pp. 441-444), 'overt full members' of the BloodPharma group (as when King participated as a member of the team at science festivals); at others we were 'minimally participating observers' or even 'non-participating observers with interaction' (as with Lyall's briefer and more distant relationship with the other collaborators, essentially limited to quarterly project meetings). In constructing the current paper, we draw on - and draw contrasts between - the empirical data gathered from the BloodPharma research team (whom we generally refer to as 'the blood project research team') and our second dataset derived from respondents external to this team.

\section{Results and discussion}


The naming of a product can have a significant impact on the uptake by different publics (Hauskeller 2005). In thinking about 'what's in a name', we identified through our data three key features that we argue will shape expectations and acceptance of this new blood product:

\section{The new blood product's ontological status}

The first, fundamental issue is the question of this blood product's ontological status. For reasons discussed below, the blood project research team has always resisted describing it as 'synthetic' or 'artificial' blood. Contemporary newspaper headlines, however, constantly referred to the product in these terms. For example "Synthetic blood created by British scientists could be used in transfusions in just two years" (MacRae 2011) and "Synthetic blood breakthrough after scientists 'produce red cells from IVF embryos'" (Hough, 2010). In this respect, our research shares some parallels with the development of 'cultured meat' which has been described as an 'as-yet undefined ontological object' (Stephens 2010; see also Stephens et al. 2017; Jönsson, 2016).

Throughout the project we have observed, and in some cases facilitated, both internal and external dialogues about the ontological ambiguities presented by this research. The placing of cultured red blood cells as a liminal object somewhere between donated RBCs and synthetic blood products has implications for the development, uptake, and marketing of cultured RBCs.

We found that whether the cultured RBCs are positioned as 'natural' or 'synthetic' will impact on their uptake across different publics. For example, in our work we found that Jehovah's Witnesses would not accept the cultured RBCs, as they are considered too similar to in vivo RBCsiv. Conversely, some other respondents did not like the idea of the cultured RBCs as they 
felt they were too synthetic. Respondents, in general, exhibited a strong attachment to the familiar and well respected blood donation system currently in existence within the UK. Our sample size was too small to draw definite conclusions, but younger respondents appeared less attached to the traditional transfusion service, and were more likely to be attracted to this new product, seeing cultured red blood cells as exciting and 'sci-fi'. The Scottish Funding Council also drew parallels with the science fiction elements of this research in their public case study showcasing their priorities in funding innovation, available on the SFC website:

'It sounds like science fiction, but it's becoming science fact - growing blood on an industrial scale' $v$

With the exception of some moral and religious objections regarding use of hESCs (which was a minority view represented within our dataset), we did not get a strong sense from the research data that cultured RBCs were 'unnatural' in the sense described by Fox Keller (2008). What appears to be key is the natural/non-natural boundary as the following quotes from one of our focus groups illustrates:

'Could that not be really dodgy? Is it actual human blood?' (College group)

M4 Would it not be somewhat safer as well? There's always the risk of somebody else's blood that it could carry other diseases that have not been found out.

M2 Then again it might not be as safe anyway because it's not real, it's not like actual real, it's made in a laboratory (College group) 
The Nuffield Council on Bioethics has suggested $(2015$, p.26) that ideas about naturalness may sit atop a deeper, unarticulated sense of unease or disapproval'. Our findings partly support this view but the unease expressed by our respondents related to concerns about the future of the NHS and the potential role that commercial companies might play within the blood donation system should the BloodPharma product be developed beyond the current proof of concept stage to full scale, commercial production (see also King, 2017):

'And my sinister side would say, is there any way that a large corporation could say "and you now need to come back to us" and there would be some kind of power base. Like the genetically modified crop companies in the US who have made it so that any farmer now wanting to farm for the major supermarket chains will then harvest the grain and will need to go back to the GM company because it only has a rate of regeneration for one year only. And you are then going cap in hand again to buy more seed. And they have deliberately done that in their economic engine of "and you will need us". And so part of me is going, how can you avoid that loophole, that greed and power coming into what can be a really healthy alternative.' (Interview with Church of Scotland minister)

'I was going to ask the same, once that licence is released, here's the instructions which you can buy and go and do in your labs, what's to stop it then becoming either into unscrupulous hands or money-making organisations or whatever? Because we have a licence to produce aspirin if they cut those corners or whatever else.' (Yoga Focus Group) 
Our findings also partly accord with Nuffield's view (ibid. p.58) that '[A]nxieties about naturalness may be grounded in concerns that novel technologies disregard, undermine or interfere with these systems and processes and thereby ignore age-old, highly evolved, and reliable processes and systems'. The attachment shown by many of our respondents to the existing blood donation system accounts for some of the views expressed in relation to concerns about replacing the established, altruistic transfusion system in the UK. It could, however, be argued that the current process is not a 'natural' system in the way that the Nuffield review intended, a point that was highlighted in interview:

'So it's not a particularly natural process anyway, you are already receiving processed blood products.' (Interview with Journalist)

\section{Describing the new blood product}

The second and related issue we identified refers to the adjectives that the blood project research team members themselves use to describe this stem cell derived tissue, and how these have evolved over time. Initially, in scientific papers the researchers described the RBCs as 'in vitro' (e.g. Mountford and Turner 2011), then switched to calling them 'industrially generated' in the funding application to the Scottish Funding Council (SFC) and in subsequent annual reports to the SFC, before settling on the term 'cultured' RBCs. This might be seen as a deliberate attempt to resonate with different audiences, the readers of scientific articles being familiar with the term 'in vitro' while the SFC (whose funding scheme focused on innovation and the commercialisation of research) may have been thought to view something that was potentially 'industrially generated' more positively. 
Our data show that the BloodPharma team was particularly anxious to distance this nascent cultured blood product from previous biotechnologies, such as synthetic blood products, GM crops, and gene therapies, which did not have particularly positive reputations with the public (King 2013; 2015). Throughout the study, the blood project research team referred to the RBCs as cultured, rather than synthetic, to reinforce the point that these were 'real' blood cells rather than less attractive chemical alternatives.

Under the heading of 'Growing good blood', this research project is showcased on the SFC website where the RBCs are described thus:

'The blood cells made by the project are not synthetic or artificial, they are "as nature", just made in a lab rather than a body. ${ }^{\text {vi }}$

The blood project research team has always equated cultured red blood cells to RBCs produced in the human body, and through this used 'natural' red blood cells as an exemplar of how cultured red blood cells should look and behave. Throughout our six-year engagement with them, the blood project research team appeared to be 'anchoring' the new cultured blood product to the existing processes of blood production and donation. This was evident in their everyday talk about the project and in their laboratory practice, where laboratory processes sought to mimic the way in which red blood cells grow in the human body.

The blood project research team looked ahead to the potential regulatory pathway for this cultured blood product, and what would be required of the product to pass the stringent regulatory criteria. There is an expectation that a cultured RBC product would be regulated as an Advanced Therapy Medicinal Product (ATMP) (King, 2013). The scientific team often described the cultured blood product as a 'test case' for the regulatory system, as its 
ambiguous identity means that it straddles existing regulations for both stem cell products and blood products. In comparison to the current donation system, cultured blood products would remove the possibility of infection transfer from donor to recipient and, as red blood cells are enucleated, the product can be irradiated without loss of function. At the same time the current one-to-one model of donation is being replaced with one in which a single product is given to many recipients. The intravenous method of delivery, and the short life-span of the red blood cells, makes it unusual compared to more traditional stem cell therapies.

The blood project research team also shared an expectation that regulators would draw an analogy between 'natural' and 'cultured' RBCs, and so equivalence would have to be demonstrated between the BloodPharma product and donated RBCs, thereby facilitating the passage of the new product through the regulatory process (Mittra et al. 2015). The blood project research team anticipated that the regulators would take into consideration the fact that both in vivo RBCs and the BloodPharma product deform to pass through the tiniest capillaries in the human body, and the oxygen carrying capabilities of both types of RBC. Nevertheless, commentators in our dataset recognised the challenge of replacing an existing, familiar 'natural' product with this new one:

'I think the issue is would you take proper blood or BloodPharma blood, that's the risk the regulators see, forget what the patients see. We are in the advantage and disadvantage, and we did say that to the EMA [European Medicines Agency], that we have a really well known product to compare it against. And we will have to prove that our product is as safe, or safer, or more efficacious, than this.' (Member of the blood project research team involved in regulatory affairs) 
Whilst strict regulation of laboratory products is the norm, ultimately how exactly the cultured RBC product is regulated will also be influenced by policy makers and the framing of the RBC product within future debates.

\section{Branding the new blood product}

Public engagement has always been a key aspect of the BloodPharma project. The team used in vivo RBCs in promoting their work, with exhibits at science festivals talking about the current blood donation system and allowing participants to view their own red blood cells. In this way the BloodPharma product was again being anchored to the familiar and presented as simply a continuum of the current system of acquiring red blood cells from human donors. It should be noted that the key project members interviewed already had an intimate knowledge of the current blood systems in the UK and Ireland and therefore were predisposed to making this association.

In their study on the use of 'naturalness' in public and political debates about science, technology and medicine, the Nuffield Council on Bioethics (2015) found noticeable differences between the ways the idea of naturalness is invoked by scientific organisations compared with other groups included in the study:

'within the publications of organisations representing scientists, value-laden uses of the words natural, unnatural and nature were almost non-existent, suggesting that many scientists do not generally see naturalness as connected to value' (ibid. p.7) 
Moreover, they found that terms such as 'artificial' and 'synthetic' had 'fewer evaluative associations and may be used in neutral or impartial ways in public discussions of science, technology, and medicine to refer to scientific or engineered products, and are used regularly within science to refer to processes, materials, compounds, and other entities' (ibid. p.16).

This presents a marked point of contrast with our own findings, where members of the BloodPharma team certainly shied away from referring to the cultured RBCs as 'synthetic' and very clearly made value associations with the term 'natural'.

The Nuffield Council on Bioethics (2015) concludes that:

'[M]aking a principled contrast between those things that appear natural to us, and those which do not, is ... not simple. For some, this casts doubt on the idea that any such division might be used to separate ethically acceptable from ethically problematic technologies' (ibid. p.21).

Our data reflect this complexity. The BloodPharma research team most definitely equated the cultured RBCs with 'natural' RBCs as a way of ensuring acceptance from both the public and the regulators. Our other research informants, on the other hand, were quite keen to demarcate cultured RBCs from in vivo ones. These members of the public demonstrated a strong attachment to the current 'free' blood donation system and were concerned about commercialisation. In some respects they found it easier to anchor cultured RBCs to a therapeutic product (rather than to 'natural' RBCs) and were more accepting of the route to commercialisation if they drew the distinction between 'natural' donated in vivo blood and a 'synthetic' therapeutic product akin to a drug. This is likely to be anchored in the experiences and knowledge of both groups, with the blood project research team having an in-depth 
knowledge of the biological basis of RBCs, whilst the other respondent groups have more experience of being a consumer of such products and therefore are more likely to value products through that consumer lens. As the scientific research progressed, there was then a further discussion about how the product should be branded once it reached the market and this saw a change in the overall project name from 'BloodPharma' to 'Novosang'. One interview respondent commented that if the team did not find their own name for the product, then the media would have to come up with something (such as 'synthetic') that was 'short and snappy'.

Although the original Wellcome Trust funded project was titled 'BloodPharma', the team made the decision to develop a new name for the introduction of the research consortium. This was partly to signify the start of the new consortium, and also because BloodPharma had always been considered a temporary name that was not well liked by some of the team members. An external branding company was tasked with the development of various names and possible branding identities for the consortium.

As part of this process, participants in our focus groups were presented with a series of names that had been put forward by the marketing team involved with the Novosang project, and also names suggested by previous focus groups. They were asked to discuss these and also put forward their own suggestions, as this extract illustrates:

“F1 'Red-O-Neg' sounds a bit...

M1 Sounds like it's by Asdavii.

F1 Sounds like a bad beer, something really nasty. In vitro. 
M2 I quite like 'manufactured blood'. I think with 'universal blood' you start thinking of the universal donor.

F1 I don't know if everyone, if the general public would understand the phrase 'in vitro'." (Focus group with medical students)

In the end 'Novosang', meaning 'New Blood' was chosen by the consortium as the brand name to represent the cultured RBC product. Novosang was the most popular option within the team and also one that did not overlap with any brand names currently in well-known use.

\section{Conclusion}

We have argued that how cultured red blood cells are positioned relative to 'natural' (in vivo) red blood cells from donation or 'synthetic' chemical blood alternatives could impact on the uptake of such products by wider society. This may also impact on the future regulation of cultured red blood cells, when compared with natural RBCs, and on how the Novosang team seeks to market their future product within the natural/synthetic boundary.

In reference to Ferguson et al.'s (2008) call for a better 'marketing' of cultured red blood cells, discussed above, our findings show that a reliance on presenting cultured red blood cells as 'natural' may not be in the best interests of the Novosang team. Our data show that research participants were most concerned about the involvement of commercial companies in blood production but were accepting of such companies' involvement in pharmaceutical production. Given the strong attachment that participants displayed towards the current blood donation system, we recommended to the Novosang team (King and Lyall 2015) that, 
notwithstanding their own views, drawing such close parallels between the Novosang product and 'natural' donated blood may not be the best strategy. Instead, for a variety of reasons, marketing cultured RBCs as a therapeutic product, produced by a pharmaceutical company and thus equated to a 'drug' in the publics' minds, might be a more reliable route to acceptance rather than trying to persuade potential users and regulators of their 'naturalness'. What started as an issue of 'naming' and ontology may, ultimately, be resolved by expediency.

\section{Acknowledgements}

This work was funded by an ESRC CASE studentship (in partnership with the Scottish National Blood Transfusion Service and the Scottish Stem Cell Network) and by the Scottish Funding Council (SFC Grant Number 227208694) . We would like to thank the respondents who contributed to this research and the anonymous reviewers who commented on an earlier draft of this paper.

\section{References}

Barnes, B. (1983) On the Conventional Character of Knowledge and Cognition, in KnorrCetina,K.D. and M. Mulkay (eds.), Science Observed: Perspectives on the Social Study of Science. London: Sage

Barnes, B., Bloor, D. and Henry, J. (1996) Scientific Knowledge: A Sociological Analysis, London: Athlone

Bates, S. R.,Faulkner, W., Parry, S. and and Cunningham-Burley, S. (2010) 'How do we know it's not been done yet?!' Trust, trust building and regulation in stem cell research. Science and Public Policy 37(9):703 - 718 
Bessos, H., Fraser, R. and Seghatchian, J. (2008) Scotblood 2007, Tackling local and global issues in transfusion medicine - Donor recruitment, effective use of blood, stem cell plasticity, and VCJD. Transfusion and Apheresis Science 38 (1):77-83

Bryman, A. (2012) Social Research Methods. Oxford: Oxford University Press

Carsten, J. (2011) Substance and Relationality: Blood in Contexts. Annual Review Anthropology, 40:19-35

Charmaz, K. (2014) Constructing Grounded Theory. Los Angeles: Sage

Cohn, C. S. and Cushing, M. M. (2009) Oxygen therapeutics: Perfluorocarbons and blood substitute safety. Critical Care Clinics, 25

Douglas, M. (1966) Purity and Danger. London: Routledge

Dragojlovic, N. and Einsiedel, E. (2013) Framing Synthetic Biology: Evolutionary Distance, Conceptions of Nature, and the Unnaturalness Objection, Science Communication, 35(5) 547 $-571$

EuroBloodSubstitutes http://cordis.europa.eu/project/rcn/75269_en.html (last accessed $13 / 3 / 16)$

Ferguson, E., Prowse, C., Townsend, E., Spence, A., van Hilten, J.A. and Lowe, K. (2008) Acceptability of blood and blood substitutes, Journal of Internal Medicine 263 (3):244-255

Fleming, P., Ferguson, E., Townsend, E. and Lowe, K.C. (2007) Perceptions in transfusion medicine: a pilot field study on risk and ethics for blood and blood substitutes, Artificial Cells, Blood Substitutes, And Immobilization Biotechnology 35 (2):149-156 
Fox Keller, E. (2008) Nature and the Natural, BioSocieties 3, 117-124

Hauskeller, C. (2005) Science in touch: functions of biomedical terminology, Biology and Philosophy, 20:815-835

Hansen, A. (2006) Tampering with nature: 'nature' and the 'natural' in media coverage of genetics and biotechnology, Media, Culture \& Society 28(6): 811-834

Harvey, D. (1996) Justice, Nature and the Geography of Difference, London: Blackwell.

Hough, A. (2010) Synthetic blood breakthrough after scientists 'produce red cells from IVF embryos', Telegraph, 16 August. Available at:

http://www.telegraph.co.uk/news/health/news/7947628/Synthetic-blood-breakthroughafter-scientists-produce-red-cells-from-IVF-embryos.html (accessed 09/03/2017)

Jasanoff, S. (2005) In the democracies of DNA: ontological uncertainty and political order in three states, New Genetics and Society, 24 (2), 139-155

Jönsson, E. (2016) Benevolent technotopias and hitherto unimaginable meats: Tracing the promises of in vitro meat, Social Studies of Science, 46(5) $725-748$

King, E. (2013) Blood, Sweat and Tears: a Case Study of the Development of Cultured Red Blood Cells for Transfusion, PhD thesis, University of Edinburgh

King, E. and Lyall, C. (2015) Eliciting the views of the wider public regarding the potential introduction of cultured red blood cells for transfusion, Confidential project report Workstream 7 Industrially generated red blood cells for transfusion (February 2015) 
King, E. (2015) Biodiversity and perceptions of risk: Reactions to the use of a single donor for stem-cell-derived red blood cell transfusions, Journal of Medical Law and Ethics, 3

King, E. (2017) Who is my donor? in Pavone, Vincenzo, Goven, Joanna (Eds.) Bioeconomies: Life, Technology, and Capital in the 21st Century p303-323. PLACE?: Palgrave Macmillan

Kronberger, N. (2015) Of worlds and objects: scientific knowledge and its publics pp. 358-368 in Cambridge Handbook of Social Representations, Sammut, G., Andreouli, E., Gaskell, G. and Valsiner, J. (eds.). Cambridge: Cambridge University Press

Li, G., Sun, T.W., Luo, G. and Zhang, C. (2017) Efficacy of antifibrinolytic agents on surgical bleeding and transfusion requirements in spine surgery: a meta-analysis, Eur Spine J. 2017 Jan;26(1):140-154

Lowe, K. C., Farrell, K., Ferguson, E. M. and James, V. (2001) Current perceived risks of transfusion in the UK and relevance to the future acceptance of blood substitutes, Artificial Cells, Blood Substitutes, and Immobilization Biotechnology 29 (3):179-189

Lyall, C. and King, E. (2016) Using qualitative research in biomedical innovation: the case of cultured red blood cells for transfusion, BMC Research Notes, 9:267-275

MacRae, F. (2011) Synthetic blood created by British scientists could be used in transfusions in just two years, Daily Mail, $28^{\text {th }}$ October. Available at: http://www.dailymail.co.uk/health/article-2053829/Artificial-blood-stem-cells-usedtransfusions-just-years.html (accessed 09/03/2017) 
Marcu, A., Gaspar, R., Rutsaert, P., Seibt, B., Fletcher, D., Verbeke, W. and Barnett, J. (2015) Analogies, metaphors, and wondering about the future: Lay sense-making around synthetic meat, Public Understanding of Science, 24(5): $547-562$

Marcus, G. E. (1995) Ethnography in/of the world system: The emergence of Multi-sited Ethnography, Annual Review of Anthropology, 24: 95-117

Marks, N. J. (2010) Defining stem cells? Scientists and their classifications of nature, The Sociological Review, 58, Supplement s1:32-50

McRoberts, R.J., Beard, D. and Walsh, T.S. (2007) A study of blood product use in patients with major trauma in Scotland: analysis of a major trauma database, Emergency Medicine Journal 24(5):325-329

Mittra, J., Tait, J., Mastroeni, M., Turner, M., Mountford, J. and Bruce, K. (2015) Identifying viable regulatory and innovation pathways for regenerative medicine: a case study of cultured red blood cells, New Biotechnology, 32(1): 180-190

Moscovici, S., (1961/2008) Psychoanalysis: its image and its public. Edited by G. Duveen, trans. D. Macey. Cambridge: Polity Press

Mountford, J. C. (2008) Human embryonic stem cells: origins, characteristics and potential for regenerative therapy, Transfusion Medicine 18 (1):1-12

Mountford, J. C., and M. Turner (2011) In vitro production of red blood cells, Transfus Apher Sci $45(1): 85-9$ 
Nuffield Council on Bioethics (2015) Ideas about naturalness in public and political debates about science, technology and medicine. Analysis Paper, November 2015, Nuffield Council on Bioethics, London

Parry, S. and Dupré, J. (2010) Introducing nature after the genome, The Sociological Review, 58, Supplement s1: 3-16

Siegrist, M. (2000) The influence of trust and perceptions of risks and benefits on the acceptance of gene technology, Risk Analysis 20 (2):195-204

Starr, D. (1999) Blood: an Epic History of Medicine and Commerce: PLACE? Little, Brown and Company

Stephens N. (2010) In vitro meat: Zombies on the menu? Scripted 7(2): 394-401

Stephens, N., King, E. and Lyall, C. (2017, in press) Blood, meat, and upscaling tissue engineering: promises, anticipated markets, and performativity in the biomedical and agrifood sectors", Biosocieties

Strauss, A. L. and Corbin, J. (1994) Grounded Theory Methodology. In Handbook of Qualitative Research, edited by N. K. Denzin and Y.S. Lincoln. London: Sage

Swierstra, T., van Est, R. and Boenink, M. (2009) Taking Care of the Symbolic Order. How Converging Technologies Challenge our Concepts, Nanoethics, 3:269-280

Thorne, S. (2000) Data analysis in qualitative research, Evidence Based Nursing, 3(3):68-70.

Titmuss, R. M. (1970), reissued 1997. The Gift Relationship: From Human Blood to Social Policy, London: LSE Books 
Trakarnsanga, K., Griffiths, R. E., Wilson, M. C., Blair, A., Satchwell, T. J., Meinders, M., Cogan, N., Kupzig, S., Kurita, R., Nakamura, Y., Toye, A. M., Anstee, D. J. and Frayne, J. (2017) An immortalized adult human erythroid line facilitates sustainable and scalable generation of functional red cells, Nature Communications, Vol. 8, 14750, 14.03.2017

Voelklein, C. and Howarth, C., (2005) A Review of Controversies about Social Representations Theory: A British Debate. Culture \& Psychology, 11(4): 431-454

Vogelstein B., Alberts B. and Shine K. (2002) Please don't call it cloning!, Science 295: 1237

Waldby, C. (2002) Stem Cells, Tissue Cultures and the Production of Biovalue, Health: 6(3):305-323

Weltert, L., Nardella, S., Rondinelli, M. B., Pierelli, L., De Paulis, R. (2013) Reduction of allogeneic red blood cell usage during cardiac surgery by an integrated intra-and postoperative blood salvage strategy: results of a randomized comparison, Transfusion. 2013 Apr;53(4):790-7

Wright Mills, C. (1940) Situated actions and vocabularies of motive, American Sociological Review 5(6):904-913 
i http://novosang.co.uk (last accessed 20/09/16).

ii http://cordis.europa.eu/project/rcn/75269_en.html (accessed 7/2/15)

iii We do, however, need to bear in mind that, despite cultured RBCs being functionally similar to in vivo blood, the stem cell line used to produce them is a laboratory artefact, one that does not exist in the body.

iv Although Jehovah's Witnesses will accept some chemical blood products they will not accept anything containing the main blood components, so in this case cultured RBCs were too 'natural', even though they did not come from a living donor (King, 2013).

${ }^{\vee}$ http://www.sfc.ac.uk/Priorities/Innovation/casestudies/case study novosang.aspx (last accessed 14/03/17).

vi http://www.sfc.ac.uk/Priorities/Innovation/casestudies/case study novosang.aspx (last accessed 14/03/17)

vii Asda is a popular UK-based 'mid-range' supermarket, now a subsidiary of the American Walmart corporation. 